\title{
Revenue Sharing: A Problem of Federalism in Brazil
}

\author{
Compartilhamento de receita: um \\ problema de federalismo no Brasil
}

RICARDO DA COSTA NUNES*
SELENE PERES PERES NUNES**

RESUMO: Este artigo mostra que a extensão e a ineficiência do federalismo no Brasil estão associadas principalmente a lacunas na competência tributária, bem como a distorções no sistema de transferências para Estados e Governos Locais, respectivamente conhecidos como Fundo de Participação Estadual - SPF e Participação Municipal Fundo - MPF. Discutimos os conceitos de federalismo fiscal e descentralização e sugerimos mudanças que poderiam contribuir para uma melhor distribuição de recursos e para a disciplina fiscal.

PALAVRAS-CHAVE: Federalismo fiscal; relações intergovernamentais; taxação.

ABSTRACT: This paper shows that the extension and inefficiency of federalism in Brazil is mostly associated with gaps in the competence to tax, as well as to distortions in the system of transfers to States and Local Governments, respectively known as State Participation Fund - SPF and Municipal Participation Fund - MPF. We discuss the concepts of fiscal federalism and decentralization and suggest changes that could contribute to a better distribution of resources and to fiscal discipline.

KEYWORDS: Fiscal federalism; intergovernmental relations; taxation.

JEL Classification: E21; E22; H77.

\section{INTRODUCTION}

In a historical perspective, it has been observed that during the 80's and 90's, a movement of polítical and economic decentralization has taken place in contrast to the previous years. This evolution had been anticipated by Vilfredo Pareto who

\footnotetext{
* From the National Treasury Secretariat/Ministry of Finance, working at the International Affairs Secretariat/Ministry of Planning, Budget and Management, and getting a PhD in Economics from Universidade de Brasília - UnB, Brasília/DF, Brasil. E-mail: rcn@fazenda.gov.br.

* F From the National Treasury Secretariat/Ministry of Finance, working at the Ministry of Planning, Budget and Management as Economic Adviser to the Minister, and getting a PhD in Economics from Universidade de Brasília - UnB. Brasília/DF, Brasil. E-mail selenenunes@inesc.org.br.
} 
affirmed that periods of centralization would be followed by periods of decentralization, and so on, this is called "Pareto's Pendulum ". As Biondal (1997) believes and Fiori (1995, pp. 3-4) acknowledges: "No one has doubts that the political and economic moment inaugurated by the Soviet Revolution and the crisis of the 30's further reinforced after the Second World War by the economic reconstruction and the Cold War, was a period of power centralization. This movement took the shape of welfare states, socialist, or developing states, independent of the democratic nature or the authority of their governments. Today, there is a general consensus that there has been approximately one or two decades that the "pendulum" has swung towards the beginning of a new decentralizing age". In this process, are included countries with very distinct characteristics such as Argentina, where according to Murphy \& Moskovits (1997), the greatest autonomy has been given to the municipalities. According to Fukasaku (1997) China would still be in the same group, to the extent that we may observe a change in the fiscal decentralization of the total central control of the 50's to the other extreme of fiscal decentralization.

In Brazil, the 1988 Federal Constitution made alterations in the tax system, targeting an increase in the autonomy of the states and a decentralization of tax collection, causing an enormous increase the tax basis of local governments and mandatory transfers to states, municipalities and regions. At the height of centralization, from 1969 to 1975 , only $12 \%$ of the collection of Tax on Industrialized Goods - TIG ${ }^{1}$ and Income Tax - IT was automatically transferred to states and municipalities. In 1996, 47\% of IT and $57 \%$ of TIG were transferred to states, municipalities and regions. In accordance with Piancastelli \& Perobelli (1996, p. 8): “(... ) States and municipalities had a substantial increase in the participation of Union tax collection, by means of an increase in the State Participation Fund SPF and the Municipality Participation Fund - MPF distribution coefficients". In addition, the basis of the Tax on Goods in Circulation and Services - TGCS² was increased with a fusion of two different taxes on the circulation of goods and services. ${ }^{3}$ In this manner, according to Shah (1997), Brazil is, today, in fiscal terms, one of the most decentralized federations in the world.

The introduction of budget decentralization practices initiated in the last 20 years has been examined in literature, as a way to raise economic efficiency. Other branches have focused their analyses on the negative economic impacts that decentralization brought about with fiscal discipline in the countries where it was implemented. This suggests, at least, a necessity to adopt complementary measures.

This work inserts itself in the debate showing the extension and the efficiency of the federative structure in Brazil. The efficiency and extension of the Brazilian structure are in great part associated with the lack of competence to tax and the

\footnotetext{
${ }^{1}$ It is Brazilian federal value added tax - VAT

${ }^{2}$ It is Brazilian State value added tax - VAT.

3 The basis of the Tax on Goods in Circulation - TGC was enlarged with the incorporation of an old federal tax on minerals, electric energy, fuel and oil, communications and highway transportation.
} 
distortions in the transfer system, providing indications of changes that would contribute to a better distribution of resources, as well as to fiscal discipline. The first part, discuss the competence to tax and the second, the distortions of the State Participation Fund - SPF and of Municipal Participation Fund - MPF.

\section{FEDERALISM AND DECENTRALIZATION: CONCEPTS, PROS AND CONS}

The concepts of decentralization and fiscal federalism find themselves intimately related but they are not identical and neither are their effects. While decentralization refers to the transfer of functions in general from the central government to the local governments, fiscal federalism only allows the transfer of taxation capacity from the central government to the local government, many times, without central coordination. According to Aghón (1991, p. 8), "Decentralization can be defined in general terms as a transference process of functions and resources from the national or central administration to a determined state (... ) ". Or, in the words of Pozo (1990, p. 5), decentralization can even be understood as "a state regime, in which is brought the administration of the regions or settlements (land decentralization) or of some special subjects (functional decentralization) to organs independent from central power, that have corporate structure with public rights and individual ownership.

Decentralization can exist in the unitary state when there is a transference of attributes (such as the police, culture and education, for example) to the subnational governments. But in fiscal federalism, states tend to have more decentralization because there is transference of competent legislative tax to the attributes to have equilibrium. As such, it is not sufficient to say as Keen $(1997$, p. 4) says — "The essence of federalism is multileveled government" -, it is necessary to clearly define the competencies of each sphere. The central government transfers resources linked to some particular expenditures. A federative structure can be more, or less, decentralized depending on the existence of more, or less, attributions and resources transferred.

Although, in a good part of economic literature this distinction is not very clear, the authors concentrate on defending or criticizing decentralization as well as federalism, basing their justifications on economic and political arguments. In economic terms, the adoption of decentralization models has been based on the supposition of augmenting economic efficiency, as a consequence, the offer of goods is supposedly better administrated by subnational governments, that is in accordance with Oates' (1972) Decentralization Theorem.

These efficiency increases, however, are only possible because they adopt some hypothesis. First, suppose that the local governments have more information in respect to community necessities that have specific characteristics. This fact permits the demand of public goods to be better attended by subnational governments. A homogeneous provision of public goods by the central government, then, would result in allocations that could be improved in Pareto's sense with local governments 
providing a differentiated level of goods to its inhabitants. Decentralization would be more efficient because it would permit the market logic to function. McKenzie and Staaf (1978) affirm that revenue sharing is a form of the government increase tax collection and/or cause a reduction in the equality and quantity of goods supplied by local governments. They assert there is not competition between the subnational government when the taxes are centralized at central level. At the same time, there is an increase in the monopoly of the subnational government.

Furthermore, there are people who affirm that federalism would be more efficient than a unitary state because it tends to promote competition between subnational governments to offer the best services at the lowest costs, stimulus that is not offered by mere transference of resources. According to Brennan \& Buchanan (1977, p. 183): "revenue-sharing is undesirable, because it subverts the primary propose of federalism, which is to create competition between jurisdictions". It would also be possible to identify externalities of expenditures between the states or problems relative to charging export tax between them, and attend to the principle of fiscal correspondence by which the financing of each marginal expenditure should be related to community benefit.

Second, suppose that decentralization would increase the citizen's participation. As such, in political terms, decentralization is seen as a way to deepen the collective participation in decision making, a distinct situation prevalent in governments with little democracy. As Guimarães (1993, p. 19) exposes: "it is supposed that an institution of federalism, while proportioning smaller geographic areas with political representation, creates conditions for the manifestation of the values and interests in separate locations" .

The redemocratization in Spain, for example, was accompanied by an increase in regional autonomy. While in the 70's the expenditures of the subnational governments represented 10\% of the GDP, in the 90's, after President Franco left the government and the assumption of a democratic government, this percentage reached $20 \%$ of the GDP. A similar process occurred in Brazil. During the period of military government, the budget was very centralized and, since the beginning of democratization, decentralization has been demanded as a part of the process.

Third, assume that the participation would reduce the corrupt practices and the adoption of measures without technical fundamentals, only directed towards attending political interests. So, there are also people who assert that there exists a correlation between democratization and economic efficiency. According to the World Bank (1983), the greatest proximity between the public administration and the voters would permit a deconcentration of public service, which would be accompanied by greater economic efficiency so there would be less corruption and less demands of an exclusively political nature. Smaller Public Firms with tighter administration would produce goods in accordance with electoral demands.

Beyond proportioning greater allocated efficiency, decentralization is also appointed as a form to increase distributive efficiency. According to Gatica \& Schilling (1997), decentralization acts in the sense of elevating equality of distribution and according to Campbell (1997) e Bremaeker (1991, p. 91): "Nothing is more stimulat- 
ing than the creation of new municipal units that, beyond bringing the figure of Public Power to act more and more in the interior of the country, promote better redistribution of public resources to the national territory". Baer (1996) sees this aspect as the element that explains the reduction of economic differences between the South and the North of the USA: "as the greatest political representation is in the South, they demanded the installation of weapons and aerospace industries there".

Although the models of decentralization have been diffused, using these suppositions as a basis, they are not immune to criticism. First, the idea that the local production of public goods is more efficient is questionable. If there are scale economies, the production of public goods by the central administration can be more productive. According to Oates (1972) and Musgrave \& Musgrave (1989), even though the supply of street illumination and fire protecrion are services better executed by subnational government, the same does not apply to the supply of some goods like justice and defense, they pertain to the national government. In fact, not all of the supply of public goods must be decentralized but only those parts which the local characteristics impose a heterogeneity on goods in which the production cost is not affected by questions of scale.

In addition to this, some decisions demand a national perspective to promote the best conduct in the local view but it is not very good conduct at the national level. This is the case of investments, in which it is necessary to consider a public good's externality, so in spite of the fact that the local scale does not justify its realization, the national perspective can recommend it. Furthermore, broad planning is necessary to avoid the action of free riders, in which a local government decides not to produce certain goods because they are produced by neighbouring regions. This is also the case of taxation, another particular problem of decentralized systems. In a federalist decentralized system, in which the subnational governments can freely choose the tax base and have some level of monopoly on the production of certain products, iy is possible that some states want to export the tax, transferring part of the taxes to inhabitants from other states. The most frequent situation is that some subnational governments offer tax benefits, creating fiscal war and therefore decreasing tax revenue at the national level. According to Ohmae (1993), private capital looks for the states that give more incentives and an infrastructure that results in scale economies for the firms. The same phenomenon can be observed between countries. Chua (1995) shows that the tax load is greater in the developed countries than in the poorer ones. The reason pointed out is that the developing countries use the interest rate to be competitive in the dispute for foreign capital, while the rich countries use more productive labour and infrastructure to attract external capital.

The fiscal war is defined by Cavalcanti \& Prado (1998, p. 8) as "a case of a general class of phenomena that emerge when political initiatives (the use of fiscal benefits and tax incentives) from subnational governments acquire negative connotations and create perverse economic effects, so in consequence of the insufficient character or conjecturally inoperant of the political and the institutional picture, that regulates the federative conflicts, which reveals itself incapable to guarantee a 
minimum equilibrium between local interests in manner that avoids perverse macroeconomic effects.

There is still the question about distributive efficiency in decentralized federalism systems. The citizens of communities can have different opinions about income redistribution programs and probably the people who live in little settlements are much more interested in the improvement of the economic situation for their citizens.

As such, the implementation of income distributive policy in some determined localities could be impeded by the entrance of beneficiaries (poor people) and by the exit of taxpayers (rich people) who do not want to help improve income distribution. Then, a substitution of the federal government by subnational authorities in the conduct of income policy is rejected by Porto \& Sanguinetti (1997). Boisier (1996) does not believe that fiscal federalism is ao element that helps income redistribution between regions. Fukasaku (1997) cites China's case, in which the decentralization process decreased the central government's financial resources and consequently its power to decrease regional disparity between rich and poor states. Ahmad (1997) also indicates the existence of this trade-off between decentralization and redistribution, but relates the experience of some countries where it was possible to decrease and, in various cases, to eliminate it.

Fundamentally, the first criticism is in respect to the fact that there is a loss of fiscal discipline with the introduction of budget decentralization practices because the national and subnational government economic policy objectives are in conflict. While, the national governments have the elevation of their popularity indices (that vary in function with the level of unemployment, price stability and growth of available income) as primary objectives, the subnational governments want to do public works.

The states and municipalities do not spontaneously and autonomous incorporate in their polices the objectives that target short period macroeconomic equilibrium, but look first to satisfy the social necessities and, in a less important level, stimulate a more efficient utilization of resources and correct the distortion in the distribution of income. Education, health, housing, security, roads and programs of income support to the poor are the preoccupations that predominate during the process of budget elaboration and execution of the states and municipalities. In Ethiopia, though the country has realized a federal public account adjustment, the deficit of the subnational governments increased due mainly to expenditures with wages, see the World Bank (1997).

Ardeo \& Villela (1995) present the explanation of the fiscal count deterioration of the states and municipalities in Brazil. According to those authors there would have been ao automatic increase of the expenses in a stable price environment and because of borrowing money with higher interest rates in the private sector. This Joan is based on future tax revenue and is called Anticipation of Budgetary Revenues. This money is used to pay the payroll, not to pay the public debt. For them, the interest policy of the government does not have a great role in state financial deterioration because the state would only be rolling over the debt with a null interest rate with the public sector. However, one must observe that the increase of pension 
benefits given by the Federal Constitution of 1988, as for example, the concession of public worker rights to the civil worker, was passed on to state constitutions.

The economic policy opposition between the central and subnational governments was greater in Brazil in the past, during the period of the First Republic, between 1888 and 1930, when the autonomy of the Brazilian states repudiated all federal interference. Each state had its own Constitution. Frequently, the regional targets were implemented in detriment to the general government. Not even the political parties could harmonize the regional objectives with the nacional ones. The parties could not form nacional policies due to regional interests either. This fact did not go unnoticed by Getúlio Vargas, the President of Brazil, who used that fact to justify the end of political parties, state constitutions and flags, centralizing the economic political power of Brazil in 1937.

As such, on one side, the subnational government's tax power and the increase of transference decrease the central government's available resources and its capacity to implement stabilization policy and, on the other hand, the expenditures of state and municipal governments tend to gain importance in relationship to the federal government. In electoral years, there is a tendency to worsen subnational government fiscal results, as pointed out by por Poterba (1994, p. 799): "In gubernatorial election years, tax increases and spending cuts are both significantly smaller than at other times". For this reason, Pozo (1990) affirms that neither is decentralization synonymous with democracy nor with greater local community participation, and this last affirmation does not implicate greater efficiency in government resource administration.

Laffont \& Senik-Leygonie (1997) cite the case of China in which, after the decentralization, the province responsible for the collection of taxes started to contribute less to the financing of central government budget revenues to benefit their own revenues. After, they adopted the responsibility regime, where each province has the function of collecting and transferring resources to the central government in a pre-established quota, being able to retain the surplus. The consequence, according to Cardoso (1996), was a fall in collection because the subnational governments learned to hide resources and create revenues and extra-budget expenditures. This policy was facilitated because the central government did not have sufficient information about the activities of subnational governments. The result of this model is also described by Shah $(1997$, p. 20): "Due to a lack of fiscal resources and policy instruments, the central government saw itself in the difficult position (greater each time) of reaching the goals of macroeconomic stabilization, regional equalization and provision of public goods".

Various authors, such as Ter-Minassian (1997) for example, have suggested complementary measures to permit the increase of economic efficiency to be accompanied by fiscal discipline. This is the position of Aghón (1997): "The processes of fiscal decentralization that are occurring in Latin America can contribute to greater effectiveness in public policies. In this sense, the strengthening of the subnational governments as directly responsible of the decentralized public expenditure, and of a greater local fiscal effort, requires adequate modalities of intergov- 
ernmental transference, improved significance in subnational tax administration, such as an ordered use of indebtedness. Artana \& Murphy (1997), Perry \& Huertas (1997) e Spahn (1997) assert that decentralization can be compatible with the macroeconomic policy objectives when there is coordination between fiscal policies of different government levels. The coordination of the macroeconomic policy requires that it creates restrictions on the subnational governments' indebtedness to assure the government's consolidated results. On the contrary, the growth of public debt and of the current expenditures could prejudice the implementation of subnational and federal government economic policy. Some countries have taken careful steps in the direction of decentralization, seeking to avoid the risk of separatism and, at the same time, to limit the power of subnational governments. Italy has regionalized social and economic government functions. They plan to give the regions of the country broad powers on areas such as environmental, transportation and infrastructure policy. Also in Scotland, the creation of a parliament with tax powers, but with limited autonomy has been approved, avoiding that the local approval of tax would interfere negatively in the British goods and services market. The new parliament will be able to decide also about the distribution of resources nowadays dispensed by the central government in Scotland (US\$ 22 billion) and about local questions such as health, education, municipal administration, the judicial system, public security, road transportation and arts.

\section{THE COMPETENCE TO TAX IN BRAZIL}

In Brazil, the creation and regularization of some principal taxes is the responsibility of subnational governments but there is some limitation on their capacity. Among the state tax capacity limitations, which is established by Article 155 of the Federal Constitution, that confers powers to the Federal Senate to define the interstate export operations aliquot. The National Council of Tax Policy- NCTP establishes the parameters and conditions by which the states can give exemptions and benefits of any type, in accordance to the Complementary Law n ${ }^{\circ} 24$, January 7, 1975.

However, to stimulate investment in their territories, states have conceded various indirect benefits which resulted in a fiscal war, in opposition to the spirit of the Constitution and the Complementary Law n ${ }^{\circ} 24$ of 1975 . These laws determine that TGCS fiscal favors can only result from approved conventions in the scope of NCTP and ratified by all federation units. It must be emphasized that the NCTP decision making system has created problems because each of the participants can, with one vote, even though unjustified, veto the collective decision.

Besides this, each states' representative has the right to unlimitedly study of a determined project, and thus in definitely protract the decision-making process, which has contributed to discredit the NCTP as a forum of consensus andas a democratic instrument of state representation.

In the beginning, the fiscal war limited itself to aliquot reductions. One can cite as example, the case of Rio Grande do Sul (a state in the South of Brazil) in 
which Governor Britto affirmed having increased the TGCS of his state to $18 \%$ like São Paulo (a state in the Southeast of Brazil) did six years before, and having conceded a finance of R $\$ 253$ million to install a General Motors - GM factory. The Governor recognizes that the fiscal war is predatory and noxious to public finances, but, adds "while there is fiscal war, the government of Rio Grande do Sul will be there combating with its weapons and wishing to be the winner Ali of Kapaz's sadness (Emerson Kapaz, Secretary of Science and Technology of São Paulo) is our happiness".

Nowadays, the fiscal war also covers: the concession of loans at interest rates lower than the those practiced in the market place, the donation of land, exemptions, means of transport, light and water subsidies and infrastructure. The generation of fiscal-financial funds, whose basic funding is composed of budgetary resources and loans also plays an important role in a "triangular" operation where the deferment of the TGCS is disguised with concessions of fiscal funds that end up dech racterizing the NCTP veto procedure.

Besides the legal arguments used in São Paulo's case, the fiscal war has been defended by some analysts, such as Rosemberg (1996, p. 2) and Verillo (1997), for whom there is not fiscal loss for the states or for the society due to tax incentive of some tax collections since there is an increase of investments and consequently of the economic tax basis. Even though the firms sometimes do not pay state taxes, they pay federal taxes, which, in Brazil, are substantial and create new jobs. As such, the fiscal concessions made by the states would be a sign that there is competition in the public sector, which decreases the cost of production in the country.

This idea, however, has been considerably contested. For Castro (1997), many industries would make the investment without the incentives, that become mere "gravy", with which they diminish the cost of their investments: "With this fiscal war, Brazilian states and municipalities lose future revenue — and assume current cost in an intense dispute for investments that, almost in their totality, already have a specific address inside the national territory".

Besides that, the most important factor would not be the creation of jobs in one or another state, but the expansion of jobs in the country. The governments that release their revenues to stimulate the economy, from a certain point on, put at risk their own administrative efficiency. The budgetary effect of a tax incentive is the same as that of an expense. This action can include a reduction in national employment because the businessmen realize that it is risky to produce in an environment in which the public defict increases and the government does not invest in education, health or other essential services. The incentives given to attract investments can, at the limit, hinder the capacity to govern.

The most drastic consequence of fiscal war is, therefore, that it causes a fall in the total collection of funds of the federation, without promoting an immediate degradation of the fiscal situation of the states involved. This fact permits the process to extend itself for a long time because they do not take measures to revert it. In Brazil, this process has been possible, in part, due to the increase of federation unit revenue sharing among federation units. In contrast, the Union and subgovern- 
ments started to concentrate their efforts on tax collection that is not transferred, this worsens the distortion of the Participation Fund, which will be the topic in the next section.

It is important to remember that, while the states reduce the TGCS aliquots, the fiscal war also extends its consequences to municipalities and to whole regions.

This ends in attacking the regional fiscal policy in various manners with a fall in revenue sharing and, also, creates a state isolation policy that instigates the strengthening of the strongest and the weakening of the weakest, in spite of any national initiative to the contrary.

Even though the Federal Constitution contemplates a mechanism to end the fiscal war, they can not apply the law. Article 155 (paragraph $2^{\circ}$, XII, "g") establishes that the complementary law " regulates the process, through deliberation of the states and Federal District, exemptions, incentives and fiscal benefits will be conceded and revoked". The federal Kandir Law, that withdrew state tax from exportation of basic and semi-industrial products (such as coffee and orange juice), initially had measures to impede the dispute between governments. However, due to pressure from the governors of Ceará, Paraíba, Amazonas and Goiás, the President of the Republic vetoed this part of the law. More than that, once the law had been implemented, the states began to allege that recompensation would not be sufficient and that the Kandir Law hindered their financial situation. The solution is difficult, in this case, because the governors accept expenditure of resources in a fiscal war and revenue tosses to stimulate the industrial production of their states. There is still a possibility that the Judiciary Power can intervene, altering the competencies. The Constitution establishes that it is beyond the Senate's functions to define the rules of indebtedness for the federation units. However, the state and municipal debt grew at the same time as the Senate that sanctioned the state and municipal bond issuance, without clearly defining the fiscal consequences. The states, in their tum, have exceeded constitutional limits and designated the resources to other ends. Another element that explains the debt, relative to the "state bonds", was the institutional practice of putting the debt in the budget at current value on the first of July for payment 18 months later, but high inflation eroded the debt. However, with the end of inflation, this mechanism that permitted a decrease in state debt has come to an end.

Besides this, although in November 27 of 1998, the Senate approved a resolution that obliged the states to use $50 \%$ of privatization revenue to pay debt, some time after, the Supreme Federal Tribunal considered that the states did not need to follow the Senate determination. Thus, the competence to tax is confusing because the federal government competes for larger tax revenues with the subnational governments. Also, the NCTP does not fulfill its role and there is even judicial interference. Besides that, the Senate has been incapable of stopping the increase of subnational government indebtedness.

At the end, it would be interesting to discuss some proposed solutions, keeping in mind that the Nacional Treasury is the competent forum to treat the tax and state 
financial subjects, one can argue that the ideal would be to transfer to the House the current attribution of NCTP for issuing norms about principal tax subjects.

The measure could contribute to avoiding conflicts between the states, that have brought about loss of tax revenue for all, and facilitate the planning of incentives that target the reduction of regional inequality. The functions of NCTP would be, as such, restricted to secondary tax subjects. It would be necessary to give to the National Treasury independence to avoid having the technical question influenced by politics. Although, according to Rezende \& Afonso (1988, p. 13), "the imposition of legal limits shows relative inefficiency in control of indebtedness, given the possibility of other forms of credit”.

Another solution to finish the fiscal war between the states, proposed in Tax Reform, would be federalization of TGCS and the fusion of TGCS with TIG and other taxes. Yet, there is much resistance. Centralization in the federal sphere of norms referring to definition of aliquots and incentives. This mechanism is considered a procedure which restricts the tax autonomy of subgovernments.

Some governments would even accept the federalization of the TGCS, since the states maintain the responsibility for collection. Those governments are interested in keeping secretaries to preserve the power to name bureaucrats who distribute favors, not in maximizing state revenue.

\section{REVENUE SHARING IN BRAZIL}

In Brazil, tax collection is predominately centralized and fiscal revenue sharing is very high, responding, in good part, to fiscal decentralization. This scheme would tend to avoid the bad effects of competition between the states and the negative externality resulting from taxation on paid taxes. Centralization permits one to deduct tax payment from one level to another. In this respect. Keen $(1997$, p. 15) affirms: "Concurrency creates an evident vertical fiscal externality between levels of government: the basis of each depends, through the responses of the taxed sector, on the rate set by the other."

However, a substantial parcel of the collected resources by the federal government does not remain in its power because it is transferred in different percentages to other entities of the federation. In view of this, the Union creates parafiscal mechanisms not subject to the participation of the states and municipalities. This Constitutional imposition has been responsible for the tendency, verified since 1989. This is the case of Social Financial Contribution - SFC and of Contribution On Liquid Profit that, in 1994, together represented nearly 1/5 of federal government revenue. Tax on Financial Operations - TFO, is not divided with the other spheres of power, it has been maintained at a high level, representing that year around $6.5 \%$ of the federal government revenue of that year. It is a bad kind of tax because it creates a wedge between interest paid by the borrower to invest and the interest received by the saver and. Consequently it tends to inhibit investment.

Following, are described the criterion for revenue sharing for resource distribu- 
tion between the three levels of power - Union, States and Municipalities - with particular attention to the State and Municipal Participation Funds. They are constitutional transfers: the State Participation Fund - SPF, Municipal Participation Fund- MPF, Middle-West Fund - MWF, North Fund - FN, Northeastern Fund - NF, Compensation by Exportation of Industrialized Products - CEIP and the Rural Territory Tax - RTT and Tax on Financial Operations - TFO.

The transfers from Union to States and Municipalities are clone at SPF and MPF, which are composed of $47 \%$ and $57 \%$ of gross revenue collected, respectively, with Income Tax - 1T and TIG, subtracting the fiscal incentives and restitutions. This is transferred to States, Municipalities and Regions:

IT:

$21,5 \%$ to the SPF

$22,5 \%$ to the MPF

$3,0 \%$ to the Regional Fund

$47,0 \%$ Total

TIG

$21,5 \%$ to the SPF

$22,5 \%$ to the MPF

$3,0 \%$ to the Regional Fund

$10,0 \%$ to the Exportation Fund

$57,0 \%$ Total

\section{The State Participation Fund - SPF and the distortions that it provokes}

The distribution of SPF is made by defining itself as the individual coefficient for each state, according to the establishment in Law n ${ }^{\circ} 62 / 1998$, for, in the next step, multiply the individual coefficient by the total value of the SPF. Still, according to the Law, from the total value of the SPF, $85 \%$ goes to the states from North/ Northeastern/Central-West regions and $15 \%$ to the Southeastern/South regions.

The compensatory and redistributive objective of SPF is reached when destined resources are at a percentage that each state has an amount of per capita revenue that is similar. In this sense, the relationship between liquid revenue and population is essential because the inhabitants who must be attended by public services in each state determine resource necessities.

However, a comparative analysis of the TGCS - the main tax of state competence responsible for $75 \%$ of collection - shows that the distortions are clearly evident. Mato Grosso do Sul (Central-West), for example, is in second place in collection of per capita TGCS, while Amazonas (North) is in fifth, although the Central-West and North are considered poor, because of this, these states are benefited together with the Northeastern and Central-West regions with $85 \%$ of the SPF resources.

In the Southeastern region, it has been verified that, although in per capita terms the TGCS revenue of Espirito Santo State is 24\% greater than Minas Gerais 
State, this small State received resources from SPF more than double than that of the other state. In per capita terms, the states with the least TGCS revenue are Maranhão and Piaui. However, six other states received more transfer from SPF. Sergipe also from the Northeastern region, even though it collected more than double than that of Maranhão and Sergipe, received about 60\% more resurces than those states. Although, the INCS revenue of São Paulo is 8 times superior to that of Amapá, the per capita SPF transferred to Amapá em 1991 was 368 times bigger than to São Paulo.

As such, with distribution criterion in vigor, using minor and maxim coefficients of resource distribution, privileges are given to small states, that is, those with smaller population and per capita income. For this reason, the states of Acre, Roraima, Amapá and Tocantins together received Cr\$229,7 billion from the SPF, when in 1991 their total population was 1.842.410 inhabitants, while Piaui, the poorest state of the Federation, with 2.581.054 inhabitants, received three times less, that is, Cr\$ 72,7 billion.

Poor distribution of the SPF does not restrict the fact that some poor states receive, per capita, much more, than the rich states, this is, in percentage much greater than they take out in terms of per capita TGCS revenue. Poor states receive disproportionately unequal transfers. This distortion has consequences graver than only the injustice that is committed with the populations of the less wealthy states, which certainly will have less access to public services. This system dampens the fiscal efforts of various states. For example, one can observe that resources received from the SPF represented about $60 \%$ of the liquid revenue of Maranhão State in 1995, while its own liquid revenue was less than $33 \%$ of available resources.

It is understandable that states such as Roraima, Amapá and Acre have low per capita tax collection, reaching CR $\$ 20.617$ in 1991, on average, as opposed to Cr\$ 102.198 in São Paulo. What should be considered a grave distortion is the fact that after having received the transfers of the SPF, the total available per capita resources surpassed the observed level in São Paulo. The SPF, which should be a transfer of redistributive and compensatory character, proportions resources of such a magnitude to some states that these state start to have, in per capita terms, much more money than the richest state of the federation. In 1994, in the North and Northeastern regions the relationship between the SPF/TGCS was $77 \%$, and $48 \%$ respectively, while in the Southeastern region it was about $0.02 \%$. What stimulus to fiscal effort can a state have that receives from the SPF, a compensatory and redistributive transfer title, a volume of resources 9,5 times greater than the TGCMS revenue, the most important state competence tax? Why upset the tax paying voters by collecting taxes when revenue sharing guaranties an end per capita revenue superior to that of the richest state in the country (São Paulo)? What sense does it make for a state in this situation to undertake an inspection, modernization of structure, or the collection and charging of a tax debtor?

In summary, the distortion in resource distribution of the SPF between the states results in: a) the existence of minimum and maximum coefficients corresponding to the relative position of the population and to the inverse of the per capita 
income of the states in relation to the national average; b) rigid lock in distribution at $85 \%$ to the North, Northeastern and Central West regions, and at $15 \%$ to the South and Southeastern regions; c) utilization of per capita income figures can only be known every five years, becoming available with great delay and without much confidence.

\section{The Municipal Participation Fund - MPF and the distortions that it provokes}

The distribution criteria, as established in the National Tax Code ( $\operatorname{Law~n}^{\circ} 5,172$, of October 25,1996 ) is the following: a) $10 \%$ of the total is divided between the Capital Municipalities; b) $86.4 \%$ to the other municipalities; c) $3.6 \%$, in accordance with the Decree-Law n ${ }^{\circ} 1,881$, of August 27, 1981, is distributed between the interior municipalities with more than 156,216 inhabitants

The values of restitution and fiscal incentives are discounted from the total collection of IT and TIG. From the liquid revenue, $22.5 \%$ are destined to the MPF. To calculate the MPF, one uses the participation coefficient of each state defined by the Union Account Court - UAC, with a basis in the demographic census of the Brazilian Institute of Geography and Statistics - BIGS. As such, to know the quota of each municipality, one must first calculate the participation of the state in which it pertains in accordance with annex 2 . The minimum coefficient of 0.6 is valid for municipalities with up to 10,188 inhabitants. For municipalities with more than 10,188 inhabitants and less than 156,216 inhabitants, 16 population bands were defined, each one of them having an individual coefficient.

For all the interior municipalities with more than 156.216 inhabitants, the fixed coefficient of 4.0 was determined, according to Mendes \& Faria (1995): two municipalities from different states situated in the same population band will have the same coefficient, but will not receive the same amount from the MPF, because the individual state coefficient is different.

The delivery of $10 \%$ from the MPF to the capitais is made in direct relation to the population and in an inverse relation to per capita income. For the calculation of the individual quota, one multiplies this value by the coefficient of each capital, dividing the result by the sum of the coefficients (118.75).

Besides the SPF, the municipalities receive from the state governments respectively, $25 \%$ and $50 \%$ from the collection of TGCS and Tax on Propriety of Automobile - TPA. In general, for the municipalities with large economic activity, these taxes constitute a substantial volume of resources when compared with the resources received from constitutional transferences.

In the case of smaller municipalities, however, the opposite occurs. As such, the criterion for distribution of resources from the Participation Funds are not considered available state and municipality revenue so this entails some distortion.

The MPF resources destined to each municipality consider their populations, because that is an indicator of the demand for goods and services. However, the rate of population growth should also be considered since: the larger the population growth, the greater the necessity for the expansion of the city's infrastructure. 
Having explained that, one can affirm that the inclusion of the population growth rate in the criteria of delivery to the municipalities would contribute to their amelioration.

Another problem relative to the criterion of the MPF distribution is the low limit in which the municipality is benefited by the maximum participation quota: 156 thousand inhabitants. There exists many municipalities with population superior to this limit. Thus, the $4 \%$ is divided by a very large number of municipalities, which prejudices large population municipalities. According to Mendes \& Faria (1995) the per capita income of the MPF in a sample of fifty municipalities was US\$ 0.7 per inhabitant, different from the average of US\$2.3 per inhabitant for the 380 municipalities of the sample. The conclusion is that the per capita transference of the MPF for the municipalities with large populations is less, where there is greater demand for public goods and services. On the other hand, in the opposite extreme, for the smaller municipalities - the distortion comes exactly from the fact that many municipalities do not have their own economic life but they have the right to political autonomy. Galvão et al (1997) point out the creation of new states and cities implicate fixed administrative expenditures that increase the inefficiency of the system. This is referred to as dependency of the municipalities on constitutional transferences. Rezende (1996a, p.14) affirms " (... ) the small municipalities today depend almost exclusively on transferences from the MPF and the ICM (... )". More than that, the fact that the constitutional transference to small municipalities are larger, in detriment to big cities, apparently does not reach its original target, which is to endow the municipalities with infrastructure and public services similar to big cities, to discourage emigration. However, the factor that permeares the decision to stay or not in one's city is the existence of work perspectives that proportionally increase individual income. Thus, it does not help to penalize the big centers, because rhe individuals will continue to leave their hometowns to look for better opportunities. A distribution of the remaining $90 \%$ is made in the following manner: subtract $4 \%$ to be given to municipalities with a population superior to 156 thousand inhabitants. The portion to be delivered to each municipality is a combination between municipal population and the inverse of state income per capita. The Decree-Law n ${ }^{\circ} 1.881 / 81$ reserves 3.6\% of the total MPF for distribution to municipalities of equal to 4.0 (more than 156,216 inhabitants), as for the individual coefficients. One calculates the participation dividing the total from the MPF of the Decree-Law by the sum of the coefficients (231.80) and multiplying the result by the coefficient of the municipality. The remaining $86.4 \%$ is distributed between the municipalities only in accordance with the population of each one.

Besides that, the constitutional transferences from rhe regions of large acquisitive power to the less powerful can not contribute to increasing the national per capita income. This is because, one could be extracting income from the poorer people of rich regions to rich people from poorer regions. Nowadays, from the total MPF, $35.3 \%$ is destined to Northeastern municipalities, $31.2 \%$ to Southeastern municipalities, and the other, $33.5 \%$, to the municipalities of the North, Central West and South regions. A fifth problem relates to the fact that the MPF does not 
consider if the city receives high values of TGCS delivery due to having developed economic activity. The consequence of the bad allocation of unilateral transference usually is fiscal renunciation. The cities most benefited by the delivery of the MPF can decrease the taxation to please the local electorate.

\section{CONCLUSION}

To sum up, that the increase of the transference to subnational states has inhibited collection and at the same time it has not been efficient as an instrument of migratory flow control, income distribution or for developing economy stimulus.

Those functions are pertinent to the federal budget, which should work as a way of economic planning, stimulating development to balance regions in different economic situations, promote the distribution of income and to build a stabilization policy. Galvão et al (1997) recognize the distortions already pointed out and remark that the current model is not able to diminish the regional inequality. On the contrary, if the resources were utilized by the federal budget, and this portion was mainly destined to poorer regions, the result could be a reduction of regional inequality. Thus, the question is not about criticizing the quantity of conceded subsidies by the federal government to poorer states or the amount of transferences but the model of regional development.

The comparison between the Federal Government's performance and the State and Municipal Governments' results reveals a substantial contrast in the last two years analyzed. After maintaining, in 1991 and 1992, a fiscal execution close to that performed by the Central Government, obtaining, in some moments, even superior results, the state finances presented, at the start of the "Real Plan", diverse behavior, that can not be explained only by the increase in the expenses with real interest. The opposite of what happened with Union and state firms, where one can observe the increase of primary and operational superavit in 1993/94 in relationship to the two years immediately preceding, the fiscal situation of the states and municipalities has worsened, due to an increase in primary expenses, and to an increase in the interest on the public debt. The fiscal result of the states and municipalities changed from an average operational superavit of $0.02 \%$ of the GDP in 1991/1992, to an average deficit of $0.44 \%$ of the GDP in 1993/1994.

Thus, the municipal and state governments, between 1986 and 1994, substantially contributed to increase the public sector deficit. Except the years 1989 and 1991, when the Necessities of Liquid Financing - NLF of the states and municipalities presented better performance than that generated by the Central Government and state firms, in all the rest of the years the primary result of the states and municipalities was systematically worse.

Between 1991 and 1995, in real terms, the total liquid debt of the Central Government, Central Bank and State Firms suffered an accumulated contraction of $37 \%$, while the state and municipality debts had, on the contrary, a real increase 
of $56 \%$. With this, its relative participation to the liquid debt of all the public sector practically, doubled in only 3 years reaching $38 \%$ of the total in 1995 .

It is important to state that the worsening of the fiscal situation happened at a very favorable conjuncture. Holanda (1993) explains the state crisis as a consequence of the management and administration of public debt. It is sufficient to observe that the increase of benefits conceded by the Federal Constitution of 1988, as for example, the concession of public worker benefits to many civil workers. (Many categories of civil workers become public workers).

In summary, Union adjustment does not propitiate the increase of stat erevenue, nor does the increment of the state tax revenue imply an increase in the transference to the municipalities. In the last years, the government has obtained control over public expenses with major Union adjustments and effort of the state enterprises, in comparison to states and municipalities. State and municipality expenses stop being a local question and assume growing importance in the economic stabiization process.

The deep changes, since 1998, of the tax revenue allocation between the Union, states and municipalities impoverished, in a substantial manner, the Central Government, without the transference correspondence of the responsibilities and tasks that have been performed by the Union. The foresight partition in the Constitution remained indeterminate and with overlapping functions. In other terms, the Union keeps the expenses and transferred revenue to the subnational governments. Thus, the Federal Constitution created a problem of resource collection and distribution.

The problem is snagged by the fact that even the fiscal adjustment measures of the federal government initiative tends to lose relevance because of the total of 7 million public workers, the smaller portion is found in the federal sphere: $24.6 \%$, while $49.1 \%$ is allocated to the state sphere and $26.36 \%$ to the municipalities. Besides that, the data available about state and municipality debts are not very trustworthy.

\section{REFERENCES}

AGHÓN, Gabriel (1991) "Descentralización fiscal: Marco Conceptual”. Série Política Fiscal n” 44, CEPAL, Santiago, Chile.

AGHÓN, Gabriel (1997) “ Fortalecimiento de las finanzas municipales: dificultades y nuevos desafíos para los países de la región “, in Descentralización Fiscal en América Latina: Nuevos Desafíos y Agenda de Trabajo, CEPAL, Santiago, Chile.

AHMAD, E. (ed). (1997) Financing Decentralized Expenditures: An International Cumparison of Grants, Cheltenham, England.

ARDEO, V. \& VILLELA (1995) “Credibilidade e a questão fiscal de estados e municípios”. Technical Note, Ministry of Finance.

ARORA, Vivek B. \& NORREGAARD, J. (1997) “Intergovernmental Fiscal Relations: The Chinese System in Perspect ive”. IMF Working Paper, WP/97/129.

ARTANA, Daniel \& MURPHY, Ricardo (1997) "Descentralización Fiscal y Aspectos Macroeconómicos”, in Descentralización Fiscal en América Latina: Nuevos Desafíos y Agenda de Trabajo, Santiago, Chile. 
BAER, Werner (1996) “Neoliberalismo, federalismo e política regional no Brasil”, in A Política Regional na era da Globalização, Instituto de Pesquisa Econômica Aplicada - IPEA .

BLONDAL, Jon (1997) "Federalismo Fiscal nos Países membros da OCDE, presented at the International Conference on Decentralization, Intergovernmental Fiscal Relations and Macroeconomic governance, June/16-17/1997, Brasília.

BOISIER, Sérgio (1996) "Em Busca do Esquivo Desenvolvimento Regional: entre a Caixa-Preta e o Projeto Político", in Revista Planejamento e Políticas Públicas - PPP, n” 13, jun., IPEA.

BREMAEKER, François E. J. (1991) “Os Novos Municípios Brasileiros”, Revista de Admnistração Municipal, vol. 38, $\mathrm{n}^{\circ}$ 200, jul.-set., pp. 82-92, Rio de Janeiro.

BRENNAN, G. \& BUCHANAN, J. (1977) “Towards a Tax Constitution for Leviathan”, Journal of Public Economics, 8: 255-73.

CAMPBELL,Tim (1997 ) "Innovaciones y toma de riesgos: el motor de la reforma del gobierno local de América Latina y el Caribe”, in Descentralización Fiscal en América Latina: Nuevos Desafíos y Agenda de Trabaj, CEPAL, Santiago, Chile.

CARDOSO, Eliana (1996) “A política regional chinesa: modelo ou mau exemplo para o Brasil?”, in A

Política Regional na era da Globalização, Instituto de Pesquisa Econômica Aplicada - IPEA.

CASTRO, Antônio Barros de (1997) “Guerra Fiscal e Política Regional”, in Boletim de Conjuntu ra, 17, $\mathrm{n}^{\circ} 1$, abril, Instituto de Economia da UFRJ.

CAVAlCANTI, C. E. G. \& PRADO, S. (1998) Aspectos da Guerra Fiscal no Brasil, IPEA, São Paulo, Brazil.

CORBO, Vittório \& HERNÁNDEZ, Leonardo (1994) "Macroeconomic Adjustment to Capital Inflows: Latin American Style versus East Asian Style”, Policy Research Working Paper 1377, The World Bank International Economics Department, Internayional Finance Division.

CHUA, Dale (1995) “Tax Incentives”, in Tax Policy Handbook. IMF.

FIORI, José Luis (1995) “O Federalismo frente ao desafio da globalização”, Texto para Discussão, n⿳ 336, IEI/UFRJ.

FUKASAKU, Ki (1997) "Descentralização Fiscal e Governança Macroeconômica: perspectivas asiáticas", presented at the International Conference in Decentralization, Intergovernmental Fiscal Relations and Macroeconomic governance, 06/16-17/1997, Brasília.

GALVÃO, A. C. F., RODRIGUEZ, M. L. O. F. \& ZACKE SESKI, N. F. (1997) “ De que maneira se distribuem os recursos da União? Composição regional e estadual da execução dos orçamentos fiscal e da seguridade social 1995”, p.122-141. Article presented at the XXV Nacional Economic Meeting, Recife, Brazil.

GATICA, Jaime \& SCHILLING, Marcelo (1997) “Descentralización, pobreza y distribución del ingreso",

em Descentralización Fiscal en América Latina: nuevos desafíos y agenda de trabajo. CEPAL, Santiago Chile.

GUIMARÃES, P. C. (1993). "Um Estudo sobre o Banco Mundial e o Desenvolvimento Municipal”. Master thesis presented at the Escola de Administração de Empresas de São Paulo - EAESP.

HAGEN J. von \& HARDEN I. (1996) “ Budget Process and Commitment to Fiscal Discipline”. IMF Working Paper WP/96/78, 1996.

HOLANDA, N. (1993) “Algum as reflexões sobre a política regional no Nordeste”. In A Política Regional na era da Globalização. Instituto de Pesquisa Econômica Aplicada - IPEA.

INTERNATIONAL MONETARY FUND (1996) Switzerland- Recent Economic Developments. IMF Staff Country Report No. 96/31.

INTERNATIONAL MONETARY FUND (1997) Spain - Recent Economic Developments and Select Issues. SM/97/76.

INTERNATIONAL MONETARY FUND (1996) Switzerland- Selected Background Issues IMF Staff Country Report No. 96/32

INTERNATIONAL MONETARY FUND (1997) Spain - Recent Economic Developments and Select Issues. Staff.

INTERNATIONAL MONETARY FUND (1995) “International Financial Statistics”, May. 
KEEN, Michael (1997) "Vertical Tax Externalities in the Theories of Fiscal Federalism”. IMF Working Paper, WP/97/173.

LAFFONT, J-J. \& SENIK-LEYGONIE, C. (1997) "Price Controls and the Economics of institution in China”. Development Center Studies, OECD Development Center, Paris, France.

McKENZIE, R. B. \& STAAF R.J. (1978) "Revenue Sharing and monopoly government". Public Choice 33(3): 93-97.

MENDES, M. J. \& FARIA, J. R. (1995) Fundo de Participação dos Municípios e Federalismo Fiscal. Technical Note, Central Bank.

MENDES, M. J. (1995) Restrição Fiscal a Estados e Municípios no Brasil. Technical Note, Central Bank.

MUELLER D. C (1997). "Federalism and the European union: A constitutional perspective”. Public Choice 90: 255-280.

MURPHY R. L. \& MOSKOVITS C. (1997) “O caso da Argentina “, presented at The International Conference on Decentralization, Intergovernmental Fiscal Relations and Macroeconomic governance, June/16-17/1997, Brasília.

MURPHY, Ricardo Lopez \& MOSKOVITS, Chynthia (1997) "Descentralização, Relações Fiscais Intergovernamentais e Governança Macroeconômica. O Caso da Argentina”, presented at The International Conference on Decentralization, Intergovernmental Fiscal Relations and Macroeconomic governance, June/16-17/1997, Brasília.

MUSGRAVE, Richard \& MUSGRAVE, Peggy (1989) Public Finance in theory and Practice. New York, McGraw-Hill.

OATES, Wallace (1972) Fiscal Federalism. New York, Harcourt Brace Jovanovich.

OHMAE, K. (1993) " Rise of the regions state”. Foreign Affairs. Spring.

PASTOR, Gonzalo (1993) “Fiscal Descentralization in Spain”, in Spain: Converging with the European Community. Occasional Paper ${ }^{\circ}$ 101, February. International Monetary Fund - IMF.

PERRY, Guillermo \& HUERTAS, Marcela (1997). "La historia de una crisis anunciada: regulando el endeudamiento de las municipalidades y departamentos de Colombia “. Descentralización Fiscal en América Latina: nuevos desafíos y agenda de trabajo, CEPAL, Santiago Chile.

PIANCASTELLI, Marcelo e PEROBELLI, F. (1996) “ICMS: Evolução Recente e Guerra Fiscal”. Texto para Discussão ${ }^{\circ}$ 402, Instituto de Pesquisa Econômica Aplicada - IPEA.

PORTO, A. \& SANGUINETTI, Pablo (1997). "La Descentralización fiscal, las transferencias intergbernamentales y la distribución regional y personal del ingreso", Descentralización Fiscal en América Latina: Nuevos Desafíos y Agenda de Trabajo. CEPAL, Santiago, Chile.

POTERBA, J. M. (1994) "State Responses to Fiscal Crises: The Effects of Budgetary Institurtons and Politics", Journal of Political Economy, 102 :799-821.

POZO, Hernán (1990) "Descentralización, democracia y desarrollo local". Documento de trabajo n ${ }^{\circ}$ 456, FLACSO, Santiago, Chile.

REZENDE, Fernando \& AFONSO, J. R. R. (1988) "O (Des)Controle do Endividamento de Estados e Municípios-Análise Crítica das Normas Vigentes e Propostas de Reforma”. Texto para Discussão $\mathrm{n}^{\circ}$ 132, Instituto de Pesquisa Econômica Aplicada - IPEA.

REZENDE, Fernando (1996) "O Processo da Reforma Tributária”. Texto para Discussão n 396, Instituto de Pesquisa Econômica Aplicada - IPEA.

ROSEMBERG, L. P. (1 996) “Guerra Fiscal ou Liberdade de Escolha”. Folha de S. Paulo, 17 de setembro.

SHAH A. (1997) “Federalismo Fiscal e Governança Macroeconômica. Teoria e Prática”, presented at The international Conference on Decentralization, Intergovernmental Fiscal Relations and Macroeconomic governance, June/16-17/1997, Brasília.

SPAHN, Paul Bernd (1997) "El gobierno descentralizado y el control macroeconómico", in Descentralización Fiscal en América Latina: Nuevos Desafíos y Agenda de Trabajo. CEPAL, Santiago, Chile.

TANZI, V. (1995) "Fiscal Federalism and Decentralization: A Review of Some Efficiency and Macroe- 
conomic Aspects". World Bank Economic Review (Annual World Bank Conference on Development Economics, pp. 193-212).

TER-MINASSIAN, Teresa (1996) "Borrowing by Subnational Government: Issues and Selected International Experiences". Paper on Policy Analysis and Assessment, n 96/4, April.

TER-MINASSIAN, Teresa (1997) “Decentralization and Macroeconomic Management”. IMF Working Paper, WP/97/155.

VERILLO J. (1997) “Bem-vinda a guerra fiscal”. Folha de S. Paulo, 22 de setembro.

WORLD BANK (198 3) World Development Report 1983. New York, The World Bank and Oxford University Press.

WORLD BANK (1997) Ethiopia: Public Expenditure Review. Report n ${ }^{\circ} 16593-$ ET. 